\title{
Region-level yield and area price elasticities for Chilean wheat incorporating climate variables
}

\author{
Sergio González and William Foster \\ Departamento de Economía Agraria, Facultad de Agronomía e Ingeniería Forestal, Pontificia Universidad \\ Católica de Chile, Casilla 306-22, Santiago Chile.
}

\begin{abstract}
S. González, and W. Foster. 2010. Region-level yield and area price elasticities for Chilean wheat incorporating climate variables. Cien. Inv. Agr. 37(3): 47-56. Wheat yields have increased in Chile in the last thirty years due in part to incentives, increased input use and improved varieties. Region-specific price elasticities of per-hectare yields and planted hectares are estimated using region-level data for the period 1975-2007. Price-yield and price-hectare elasticities are similar, although slightly lower than those obtained by Morales and Foster (2002) in all regions, ranging between 0.33 and 0.73 for yields and between 0 and 0.43 for hectares. Values of price elasticity for total production range between 0.38 and 1.12. For two of the regions studied, climate variables were available and their inclusion results in a reduction in of the elasticity of total production with respect to price. The results suggest that the inclusion of climate variables should be considered when estimating producer responses to prices and when projecting the likely impacts of forecasted climate changes on producer decisions.
\end{abstract}

Key words: Wheat, climate variables, price elasticity.

\section{Introduction}

Wheat is one of the most important cereal crops in Chile and the production may be found all along the national territory. The Region of Araucanía and the Region of Bío Bío covered in total $73.4 \%$ of the national wheat crop surface in 2007 , a $95 \%$ corresponded to varieties of flour wheat (INE, 2007).

Wheat yields have increased in the last 30 years, reaching in 2007 average yields of around 4.5 ton $\mathrm{ha}^{-1}$ (INE, 2007). The introduction of new productive techniques like the intensive use of fertilizers and better varieties are some of the

Received July 21, 2009 Accepted October 10, 2009. Corresponding author: sagonzac@uc.cl factors influencing this increase in yields (Mellado, 2007; Vargas et al., 2001). However, 78.5\% of the wheat is found in dryland conditions, which makes the yields depend strongly on the climate conditions of each season.

The studies in Chile in relation to the national wheat supply use econometric models at national (Irarrázabal, 1979; Briceño et al., 2005) or regional level (Morales and Foster, 2002) to estimate price-surface and price-yield elasticities. The use of econometric models has been favored due to the availability of data and the low operational cost of estimation in relation to other alternatives, like mathematical programming and the estimation of production functions (Irarrázabal, 1979; Antle and Capalbo, 2001; Morales, 2003). The role played by prices, and 
specifically the expectations of prices on wheat supply, is evident through the influence generated on sowing decisions by farmers. However, the role of prices on wheat sowing is only one aspect on the estimation of wheat supply, as it is influenced by other factors like technology and climate (Nerlove, 1958). Morales and Foster (2002) obtained regional price-yield and pricewheat surface elasticities for the period 19752000. The values of the price-yield elasticity ranged between 0.5 and 0.8 , with an average value of 0.65 ; and the values of the price-surface elasticities presented a great variation between regions, fluctuating between values of 0.3 and 0.9. Irarrázabal (1979) incorporated precipitations at a national level in the elasticity estimation in relation to price, but without significant results. The others studies do not consider the relevance of climate variables on the estimation of price-elasticity.

Recently, there have been studies about the relevance of global warming on agriculture. In these studies, the estimations of impacts depended on simulation models of potential yields, as the use of econometric models incorporating historic yields and the correlation with climate conditions are still absent. The use of models correlating only climate conditions, in regard to yields or surface, may be inadequate because the effect of price on the farmer response is not included. Likewise, estimating only the impact of prices may generate a biased result, as it excludes the effect of climate variables. The objective of this study is to estimate the response of wheat producers in Chile, in relation to the price. The basic hypothesis is that climate variables have an effect on wheat yields. Another reason to include climate variables is that it might have an impact on the response by the producer in relation to prices. The present study estimates the price-surface elasticity at regional level, following the econometric model by Morales and Foster (2002), using updated data until 2007. An innovative contribution is that this work includes climate variables for wheat yield models in two regions, where data were available, in order to compare the results on total elasticity in models with or without cli- mate variables. The use of this type of models is applicable on the projection of global warming impact and it may estimate producer responses including a wider range of factors that influence decision making by the producers, in contrast to simulation models of potential yields.

\section{Materials and methods}

There are different forms to estimate empirically the response of individual and aggregated supply in relation to prices. Regardless the estimation method used, it is expected that the supply response in relation to prices will be positive for an increase in real price of the product; negative in relation to an increase of competitor prices, since they decrease the relative price of the analyzed product; and negative for an increase of input prices . In this work, the impacts on total production were separated into two components: surface and wheat yield.

\section{Models of wheat surface}

Nerlove (1956) developed a model of distributed lags where production, sowed surface or yield may be related to the same referred lagged variable, to the lagged crop price and to the lagged input price. This model has obtained the most satisfactory response estimating farmer responses and price expectations (Fisher and Tanner, 1978; Rivera 1986). In order to estimate a functional form for producer supply, the estimations of the period mentioned were made using a Cobb-Douglas model, based on Morales and Foster (2002).

The model is based on the maximization of the net incomes, but due to the difficulty to determine this variable directly, approximations are made using gross income and crop prices. The model assumes a Cobb-Douglas functional form, which is presented below.

(1) $\ln (H)_{t}=\hat{\alpha}_{0}+\left(\hat{\alpha}_{1}\right) \ln (H)_{t-1}+\sum_{i=1}^{n} \hat{\alpha}_{i} \ln \left(I B_{i}\right)_{t-1}+\sum_{j=n+1}^{m} \hat{\alpha}_{j} \ln \left(P C_{j}\right)_{t-1}$

where:

$\mathrm{H}$ : wheat surface sowed in period $\mathrm{t}$.

IB: gross income of cultivation i.

PC: price of crop $\mathrm{j}$. 


\section{Yield models}

In order to estimate the price-yield elasticities, the model based on Morales and Foster (2002) was also used, excluding the use of yield prediction models due to their limited range of application, and the requirement of specific for local varieties and climate conditions.

The wheat yield model relates yields with prices from previous periods, tendency impacts in technological improvements, and the possible inertia in productive practices, not captured by the changes in the prices observed.

(2) $\ln (R)_{t}=\hat{\beta}_{0}+\left(\hat{\beta}_{1}\right) \ln (R)_{t-1}+\sum_{i=1}^{n} \hat{\beta}_{i} \ln \left(P C_{i}\right)_{t-1}+\delta(T)_{t}$

$\mathrm{R}$ : wheat yield in the period $\mathrm{t}$.

PC: price of crop i.

$\mathrm{T}$ : tendency.

In this model, the tendency $(\mathrm{T})$ is used to capture the technological progress, such as: the use of new machinery and techniques, incorporation of new varieties and other technological improvements. As found in the model by Morales and Foster (2002) the variable of lagged yield adds a new explanatory power statistically significant, this inertia, mainly in the regions of O'Higgins and Los Lagos, may be due to the costs of changing productive practices. The lagged yield constitutes a proxy variable to take into account and control those unobservable costs.

\section{Yield models incorporating climate variables}

Climate variables are included in the model of wheat yield model, as it is expected that climate has a more direct effect on yield than the sowed surface. The incorporation of climate variables was made only in the regions of Bío Bío and La Araucanía, because of the availability of data and also that these regions represent, as a whole, around $73 \%$ of the surface of meal wheat in Chile by 2007 (INE, 2009). For the incorporation of climate variables, we chose only data on temperatures and precipitations.

In order to include the climate variables, the requirements of degreedays and precipitations are followed. Time series in monthly mean temperatures and monthly precipitations are used. The temperature is included through the estimation of the necessary degree-day to complete each stage of development. As in drylands, there is a high influence of the monthly precipitation on yield in spring months (Mellado, 2007); the precipitations were included in the model using data from the critical month in that stage. The variables related to climate are lagged in a period (t$1)$, because the climate conditions determining the yields of the year $t$ are given in the year $\mathrm{t}-1$. A model including climate variables of temperature and precipitations is presented below:

$$
\text { (3) } \ln (R)_{t}=\hat{\beta}_{0}+\left(\hat{\beta}_{1}\right) \ln (R)_{t-1}+\sum_{i=1}^{n} \hat{\beta}_{i} \ln \left(P C_{i}\right)_{t-1}+\sum_{j=1}^{m} \hat{\phi}_{j} \ln \left(G D_{j}\right)_{t-1}+\hat{\varphi} \ln (P P)_{t-1}+\delta(T)_{t}
$$

$\ln (R)_{t}=$ natural logarithm of wheat yield in the period t.

$\ln \left(P C_{i}\right)=$ natural logarithm of price of crop $\mathrm{i}$.

$\ln \left(D G_{j}\right)=$ natural logarithm of degrees-day for the development state $\mathrm{j}$.

$\ln (P P)_{t-1}=$ natural logarithm of the precipitations of the period $\mathrm{t}-1$.

$\mathrm{T}=$ tendency.
The degree-day corresponds to the degrees accumulated over a base temperature for a phase of a specific phenologic development.

(4) $D G_{j t}=\sum_{i}^{n}\left(T B_{j}-T M_{i t}\right)^{*} L_{i}$

Where:

$D G_{j t}=$ degree-day accumulated for the state of development $\mathrm{j}$ of the year $\mathrm{t}$.

$T B_{j}=$ base temperature for the state of development j.

$T M_{i t}=$ mean temperature for the sub period $\mathrm{i}$ of the year $\mathrm{t}$. 
$L_{i}=$ length of the sub period i (corresponding to the number of days that each month has in the stage of development).

In order to estimate the requirements of degreeday for spring and winter wheat varieties, a structure of requirements of degree-days was constructed based on the average dates and base temperatures of the phenologic states of the development of spring and winter wheat in Chile, estimated by Mellado (2007). The effective degree-day for the phases of grain filling and maturity for winter and spring wheats are estimated using data on monthly mean temperature of November (TN) and December (TD). Nevertheless, it is estimated that the model using data for winter wheat is more representative of the producers of studied area. The effective degreedays for each variety and stage of development are shown in Table 1.

\section{Data Sources}

Data on surfaces, prices, yields, and gross incomes for the five regions under study (O’Higgins, Maule, Bío Bío, Araucanía and Los Lagos) were obtained from ODEPA (2009). The data on temperatures and precipitations of the region of Bío Bío were obtained from Dirección
General de Aguas (DGA), Coihueco Embalse and Quilaco meteorological stations. The data on temperatures and precipitations in the region of La Araucanía were obtained from the Puerto Saavedra, Traiguén (DGA) and Temuco (Dirección Meteorológica de Chile) stations.

It is necessary that the series used in regressions are stationary, in levels or differences, in order to carry out statistical inferences properly using time series. The augmented Dickey Fuller test was used to determine the seasonality and the integration order of the variables. According to this test, it was found that the variable "wheat surface" and other variables are not stationary and are an integration order one (I (1)) (except yields) (to see results from tests and integration refer to González (2009), attachments 3 and 4). As the sowed surface and some explanatory variables are I(1) a relation between first differences of sowed surface and first differences in independent variables were estimated as shown in the equation 1 . The estimations were made through an error correction equation system; because the proper tests showed that the surface and the explanatory variables were cointegrated. Note: According to a trace test of Johansen, for the system of 5 equations of surface corresponding to the 5 regions, there is one cointegration equation per region at a

Table 1. Effective degree-day required in the developing stages for winter and spring wheat.

\begin{tabular}{lll}
\hline Developing stage & Winter wheat & \multicolumn{1}{l}{ Spring wheat } \\
\hline Sowing to emergence & $(\mathrm{TM}+2) 20$ & $(\mathrm{TA}+2) 11$ \\
Flower initiation & $(\mathrm{TM}-2) 10+(\mathrm{TJN}-2) 30+(\mathrm{TJL}-2) 17$ & $(\mathrm{TA}-2) 16$ \\
Terminal ear & $(\mathrm{TJL}-5) 14+(\mathrm{TA}-5) 31+(\mathrm{TS}-5) 7$ & $(\mathrm{TA}-5) 4+(\mathrm{TS}-5) 22$ \\
Ear development & $(\mathrm{TS}-9) 23+(\mathrm{TO}-9) 7$ & $(\mathrm{TS}-9) 8+(\mathrm{TO}-9) 15$ \\
Flowering & $(\mathrm{TO}-10) 23+(\mathrm{TN}-10) 17$ & $(\mathrm{TO}-10) 16+(\mathrm{TN}-10) 5$ \\
Grain filling & $(\mathrm{TN}-13) 7+(\mathrm{TD}-11) 5$ & $(\mathrm{TN}-11) 20$ \\
Maturity & $(\mathrm{TD}-13) 25$ & $(\mathrm{TN}-13) 5+(\mathrm{TD}-13) 31$ \\
\hline
\end{tabular}

$\mathrm{TM}=$ May mean temperature; $\mathrm{TJN}=$ June mean temperature; $\mathrm{TJL}=\mathrm{July}$ mean temperature; $\mathrm{TA}=$ August mean temperature; $\mathrm{TS}=$ September mean temperature; $\mathrm{TO}=$ October mean temperature; $\mathrm{TN}=$ November mean temperature; $\mathrm{TD}=$ December mean temperature.

Source: Estimated based on Mellado (2007). 
level of $5 \%$ of significance. For more details on models of error correction, used to explain the variation in wheat surface in Chile, see Morales and Foster (2002). Please note that the method of estimation first involves the estimation of the cointegration equations (long term) after the equations estimation of error correction using the error of the previous estimation. There is the possibility of carrying out the same estimations using statistical packs VEC.

The variable yield was identified as stationary for the regions, according to the augmented tests of Dickey Fuller; therefore, it was decided to use a system of equations in levels. The yields have a convergent behaviour towards their line of tendency after receiving positive or negative shocks. The estimations were made as a seemingly unrelated equation system (SUR). Please note that there are two equation systems: surface, using a model of error correction, and yield, using an equation system in levels.

\section{Results}

\section{Models of wheat supply}

According to the results obtained, it is observed extended explanations of the variability in all the regions. The signs of the coefficients of the independent variables were as expected and were statistically significant, however, for this article, they were omitted because the discussion is focused on the results of the price-surface elasticity (for more details of the results, refer to González, 2009). The price-surface elasticities obtained for the regions under study and the values of square $\mathrm{R}$ are summarized in Table 2. The lowest value of square $\mathrm{R}$ was in the Region of Los Lagos, which corresponds to 0.42 .

The price-surface elasticities range between 0 and 0.43 , tending to diminish towards the Southern regions of the country. This is coherent with the fact that there are more alternatives to wheat sowing in the central regions; therefore, the wheat supply is more elastic in the central zone than in the Southern zone of the country. These values are lower than the results obtained by Morales and Foster (2002), ranging between 0.32 and 0.8 ; which is not a result from the model specification but because the additional inclusion of information, since 2000 to 2007 , decreases the price-surface elasticity.

\section{Models of wheat yield}

A summary of these results is shown, as the discussion is focused on the results referring to price-yield elasticities. It may be observed in Table 3 that the price-yield elasticities range between 0.33 and 0.73 . Although the coefficients estimated in detail were omitted, the $\mathrm{R}^{2}$ values are presented, which are higher than $78 \%$ for all regions. (Note: The detail of the estimations associated to the coefficients of the other variables is not presented (yields, prices and tendency), but these estimations were highly significant and with the expected signs. As proven by Morales and Foster (2002), the coefficients estimated associated to the lagged yields were statistically significant, as in the present work, in the regions of O'Higgins and Los Lagos. The exclusion of this variable reduces the explanatory power of the model without a notable effect on the estimated coefficient of the other variables.

Table 2. Price-hectare elasticities for the studied regions.

\begin{tabular}{lccccc}
\hline & \multicolumn{5}{c}{ Region } \\
\cline { 2 - 5 } Elasticity & O'Higgins & Maule & Bío Bío & Araucanía & Los Lagos \\
\hline $\begin{array}{l}\text { Price-hectare } \\
\text { elasticity* }\end{array}$ & 0.39 & 0.43 & 0.10 & 0.26 & 0.00 \\
$\mathrm{R}^{2}$ for the regression & 0.69 & 0.77 & 0.90 & 0.74 & 0.42 \\
\hline
\end{tabular}

*Estimated by Seemingly Unrelated Regression. 
According to the tests, the residues obtained from the regressions are stationary.

A comparison with the results obtained by Morales and Foster (2002) is presented in Table 4. In all the cases a reduction of the price-surface, price-yield and price-production elasticities (corresponding to the sum of the two first elasticities) is observed. This indicates that the contribution of additional information since 2000 reduces the elasticity; consequently, the farmer response to the price is lower.

\section{Models of wheat yield including climate variables}

The results are presented in Table 5, including the yield model with climate variables for winter and spring wheat in the Region of Bío Bío and La Araucanía. The price variable has an associated coefficient of 0.26 in winter wheat in both regions, at a level of $10 \%$ of significance. The price variable for winter wheat in both regions is not significant. Consequently, the price-yield elasticities are highly reduced, losing significance in respect to the yield model without climate variables. This means that, when the climate information is included in the yield model, it is not possible to reject the null hypothesis that the price does not have an impact in the wheat yields at $5 \%$ levels of significance. A summary of the price-yield elasticities is presented in Table 6 for the regions and the different models.

In regards to climate variables, the grain filling phase was significant for all the models at $5 \%$, except for winter wheat in the Region of La Araucanía (Table 5). The sign presented for this phase is positive, which indicates that the accumulation of degree-days during this phase promotes the increase of yields for spring and winter wheats in the Region of Bío Bío and La Araucanía. In regards to the magnitude of the increase, the effect is higher in the Bío Bío Region, specifically in winter wheat, with degree-day elasticities of grain filling phase-yield of 0.26 .

Table 3. Price-yield elasticities for the studied regions.

\begin{tabular}{lcccccc}
\hline & \multicolumn{5}{c}{ Region } \\
\cline { 2 - 6 } Elasticity & O’Higgins & Maule & Bío Bío & Araucanía & Los Lagos \\
\hline Price-yield elasticity * & 0.73 & 0.57 & 0.38 & 0.33 & 0.38 \\
$\mathrm{R}^{2}$ for the regression & 0.69 & 0.77 & 0.90 & 0.74 & 0.42 \\
\hline
\end{tabular}

*Estimated by Seemingly Unrelated Regression.

Table 4. Price elasticity comparison between present results and the ones obtained by Morales and Foster (2002).

\begin{tabular}{|c|c|c|c|c|c|}
\hline \multirow[b]{2}{*}{ Elasticity } & \multicolumn{5}{|c|}{ Region } \\
\hline & O’Higgins & Maule & Bío Bío & Araucanía & Los Lagos \\
\hline $\begin{array}{l}\text { Price-hectare elasticity obtained by Morales and } \\
\text { Foster }\end{array}$ & 0.75 & 0.80 & 0.35 & 0.30 & 0.75 \\
\hline Price-hectare elasticity obtained in this study & 0.39 & 0.43 & 0.10 & 0.26 & 0.00 \\
\hline $\begin{array}{l}\text { Price-yield elasticity obtained by Morales and } \\
\text { Foster }\end{array}$ & 0.95 & 0.70 & 0.45 & 0.45 & 0.65 \\
\hline Price-yield elasticity obtained in this study & 0.73 & 0.57 & 0.38 & 0.33 & 0.38 \\
\hline $\begin{array}{l}\text { Price-production elasticity obtained by Morales } \\
\text { and Foster }\end{array}$ & 1.40 & 1.45 & 1.15 & 0.95 & 1.55 \\
\hline Price-production elasticity obtained in this study & 1.12 & 1.00 & 0.48 & 0.59 & 0.38 \\
\hline
\end{tabular}


The maturity development phase was significant for the winter wheat from both regions, presenting $10 \%$ of significance for the Region of La Araucanía. The sign for this phase was negative in all the regressions. The precipitations in October were significant for the development of winter and spring wheat from the Region of Bío Bío, and the November precipitations were significant for the Region of La Araucanía for both wheat types, but the magnitude of the coefficients associated

Table 5. Wheat yield model results including climate variables, estimated by seemingly unrelated regression.

\begin{tabular}{|c|c|c|}
\hline \multicolumn{3}{|c|}{ Wheat model using winter variables for Bío Bío region } \\
\hline Variable & Coefficient & Probability \\
\hline Constant & -3.033550 & 0.09770 \\
\hline Wheat price $(-1)$ & 0.260645 & 0.07680 \\
\hline Trend & 0.046318 & 0.00000 \\
\hline Grain filling & 0.262228 & 0.00020 \\
\hline Maturity & -0.207290 & 0.00170 \\
\hline October precipitations & 0.000782 & 0.00010 \\
\hline $\mathrm{R}^{2}$ for the regression & 0.93007 & \\
\hline \multicolumn{3}{|c|}{ Wheat model using spring variables for Bío Bío region } \\
\hline Variable & Coefficient & Probability \\
\hline Constant & -2.801900 & 0.14000 \\
\hline Wheat price $(-1)$ & 0.219918 & 0.15240 \\
\hline Trend & 0.046143 & 0.00000 \\
\hline Grain filling & 0.131406 & 0.00270 \\
\hline Maturity & -0.066710 & 0.20210 \\
\hline October precipitations & 0.028828 & 0.00050 \\
\hline $\mathrm{R}^{2}$ for the regression & 0.924005 & \\
\hline \multicolumn{3}{|c|}{ Wheat model using winter variables for Araucania region } \\
\hline Variable & Coefficient & Probability \\
\hline Constant & -3.167740 & 0.10830 \\
\hline Wheat price $(-1)$ & 0.26498 & 0.09630 \\
\hline Trend & 0.046679 & 0.00000 \\
\hline Grain filling & 0.124206 & 0.01320 \\
\hline Maturity & -0.085950 & 0.06790 \\
\hline November precipitations & 0.034993 & 0.02380 \\
\hline $\mathrm{R}^{2}$ for the regression & 0.920364 & \\
\hline \multicolumn{3}{|c|}{ Wheat model using spring variables for Araucania region } \\
\hline Variable & Coefficient & Probability \\
\hline Constant & -3.012730 & 0.12050 \\
\hline Wheat price (-1) & 0.239209 & 0.12920 \\
\hline Trend & 0.046561 & 0.00000 \\
\hline Grain filling & 0.092426 & 0.00750 \\
\hline Maturity & -0.033640 & 0.39300 \\
\hline November precipitations & 0.033203 & 0.03490 \\
\hline $\mathrm{R}^{2}$ for the regression & 0.922478 & \\
\hline
\end{tabular}

*All variables in natural logarithm, except trend. 
Table 6. Price-yield elasticity obtained in the different models*.

\begin{tabular}{lccccc}
\hline & \multicolumn{5}{c}{ Region } \\
\cline { 2 - 6 } Elasticity & O’Higgins & Maule & Bío Bío & Araucanía & Los Lagos \\
\hline Price-yield without climate variables & 0.73 & 0.57 & 0.38 & $0.33^{* *}$ & 0.38 \\
Price-yield elasticity winter wheat model & 0.72 & 0.56 & $0.26^{* *}$ & $0.26^{* *}$ & 0.36 \\
Price-yield elasticity spring wheat model & 0.72 & 0.56 & 0.00 & 0.00 & 0.36 \\
\hline
\end{tabular}

*Estimated by Seemingly Unrelated Regression.

**Significant at a $10 \%$ level of significance.

is very small, therefore, their effect on yields is minimal. The tendency variable is significant in all the models, which makes evident that the technological progress has played an important role on the increased wheat yield since 1985 .

An $\mathrm{F}$ test was made to determine if the climate variables included are relevant in the model. The null hypothesis that the explanatory variables are simultaneously equal to 0 is rejected in the regressions of the Region of Bío Bío at significance of $5 \%$, and in the regression of wheat yield using spring data in the Region of La Araucanía at $10 \%$ of significance. The null hypothesis that the variables are simultaneously equal to 0 in the equation of winter wheat of the Region of La Araucanía cannot be rejected. The lagged price, the precipitations of November and the maturity phase were not significant in this regression; therefore, this result is expected.

A test was carried out to verify the homoscedasticity of the errors obtained in the equations and to discard heteroscedasticity problems as a result of the inclusion of climate variables. The test does not indicate evidence to reject the null hypothesis of homoscedasticity for the errors in any of the yield regressions that include climate variables.

\section{Discussion}

Wheat supply became more inelastic with the inclusion of additional information corresponding to the period 2000-2007. However, the role played by price on sowing decisions is still im- portant, especially in the regions located in the central zone.

The inclusion of climate variables reduces the level of statistical significance for prices. The values of the price-yield elasticity and their statistical significance decrease when the climate variables are included. This result shows that it is possible to overestimate the price-yield elasticity if the climate variables are excluded. It is possible that this result may be applied to the other regions under study. Future research must consider this factor carefully for estimations of the sensibility of sowed surface and yield against wheat price in Chile. A possible source of this impact is found in the nature of the prices in the model. As annual averages, prices are imperfect reflections of the real incentives of the producers, in addition, there is a time overlap between climate variables and prices, therefore, there is a possibility that the average price has already included the effects of the climate variables. Further research is required to determine more precise price measures and to improve the measurement of the factors which are incentives for higher yields for the producers.

The increase of yields, according to the models exposed, suggests that there are technological variables, like the introduction of productive techniques and new varieties, playing an important role on yields increase. The yields favoured from the accumulation of degree-days during the grain filling phase, for spring wheat and for winter wheat. On the other hand, wheat yields are influenced negatively by the accumulation of degree-days in the maturity phase, which may 
be due to the incidence of weeds, plagues and diseases benefited from the accumulation of degree-days; the logical explanation is that during the phase of maturity development, the accumulation of degree-days, in addition to favour the wheat development, generates even more favourable conditions for the development of weeds, diseases and plagues. This hypothesis requires further research.

There are currently numerous models predicting potential wheat yields. These models are built based on experimental data obtained for specific areas and varieties; therefore, their range of application is limited. Antle and Capalbo (2001) have developed Econometric Process Models which may simulate the modelled behaviour estimated out of the spatial range of application. However, this is not a solution to the difference produced between the real productivity and the theoretical productivity because the potential yields of crops are used.

These facts suggest that the use of econometric models, including both climatic and economic variables, is essential for estimating the effects exerted by the climate change, as these factors must be studied as a whole to model more precise responses in regards to yields and farmer behaviour.

\section{Acknowledgements}

We thank the Oficina de Estudios y Políticas Agrarias, Ministry of Agriculture, Government of Chile for the provision of information to carry out this research, and the contribution of Dr. André Laroze, chief of the Unit of Climate Change of the same institution.

\section{Resumen}

\section{S. González y W. Foster. 2010. Elasticidad precio-rendimiento y precio-superficie de trigo} en Chile a nivel regional incorporando variables climáticas. Cien. Inv. Agr. 37(3): 47-56. Los rendimientos de trigo han aumentado en Chile en los últimos 30 años, llegando a obtener rendimientos promedio del orden de 4,5 ton ha ${ }^{-1}$ al año 2007. Este aumento en rendimientos se debe en parte al progreso tecnológico. Se realizan estimaciones de elasticidades preciosuperficie y elasticidades precio-rendimiento, actualizando un modelo planteado por Morales y Foster (2002). El trabajo incorpora variables climáticas a modelos de rendimiento de trigo en dos regiones para las cuáles había datos disponibles con el propósito de comparar los resultados sobre la elasticidad total en los modelos con y sin variables climáticas. Las elasticidades para el periodo actualizado se reducen en relación a las obtenidas por Morales y Foster (2002). Al incorporar datos climáticos la elasticidad precio-rendimiento se reduce en magnitud y en nivel de significancia estadística. Este resultado demuestra que es posible sobreestimar la elasticidad precio-rendimiento si no se incluyen las variables climáticas. La investigación a futuro debe tomar en cuenta esta consideración y se debe ser cuidadoso con las estimaciones de la sensibilidad de la superficie sembrada y de rendimiento frente a los precios del trigo en Chile.

Palabras clave: Elasticidad precio, trigo, variables climáticas. 


\section{References}

Antle, J., and S. Capalbo. 2001. Econometric-process models for integrated assessment of agricultural production systems. American Journal of Agricultural Economics 83(2):389-401.

Briceño, F., A. Rojas, and I. Coydán. 2005. Políticas de precios en Chile. El caso de los cereales. Panorama Socioeconómico 23(31): 58-70.

Fisher, B.S., and C. Tanner. 1978. The Formulation of price expectations: an empirical test of theoretical models. American Journal of Agricultural Economics 60(2): 245-248.

González, S. 2009. Modelos de oferta de trigo en Chile, incorporación de variables climáticas. Tesis de Magíster, Facultad de Agronomía e Ingeniería Forestal. Pontificia Universidad Católica de Chile. Santiago, Chile. 66 pp.

INE - Instituto Nacional de Estadísticas, INE. 2009. Bases de datos Censo Agropecuario 2007. Santiago, Chile. Available online at: http://www.ine. cl (Website accessed: January 20, 2009).

Irarrázaval, R. 1979. Respuesta a precios del hectareaje, la producción y los rendimientos de trigo y maíz en Chile. Ciencia e Investigación Agraria 6(2): 135-149.

Mellado, M. 2007. El trigo en Chile: cultura, ciencia y tecnología. Instituto de Investigaciones $\mathrm{Ag}$ - ropecuarias, Centro Regional de Investigación Quilamapu. Chillán, Chile. 684 pp.

Morales, L., and W. Foster. 2002. Modelo de corrección de errores en funciones de oferta de trigo a nivel regional en Chile. Ciencia e Investigación Agraria 29(2):101-114.

Morales, L. 2003. Análisis de la política triguera nacional. Tesis de Magíster, Facultad de Agronomía e Ingeniería Forestal. Pontificia Universidad Católica de Chile. Santiago, Chile. $52 \mathrm{pp}$.

Nerlove, M. 1956. Estimates of the elasticities of supply of selected agricultural commodities. Journal of Farm Economics 38(2):496-509.

Nerlove, M. 1958. The Dynamics of Supply: Estimation of farmers response to price, The John Hopkins Press, Baltimore, EEUU. 268 pp.

Oficina de Estudios y Políticas Agrarias (ODEPA). 2009. Serie de precios agrícolas y estadísticas sectoriales. Available online at: http://www.odepa.gob.cl Website accessed 2009.

Rivera, L. 1986. Un análisis empírico sobre la elaboración de expectativas de precios. Investigaciones Económicas 10(1): 201-210.

Vargas, G., W. Foster, and P. Parodi. 2001. Competitividad de la producción de trigo en el sur de Chile. Informe preparado para Fundación Chile. Departamento de Economía Agraria, Pontificia Universidad Católica de Chile. 44 pp. 